\title{
Community Resistance against Sand Mining Activities at the Brown Canyon Semarang
}

\author{
Angga Satria Wicaksana ${ }^{1}$, Amirudin Amirudin ${ }^{2}$ \\ ${ }^{1}$ Department of Social Anthropology, Faculty of Humanities, Universitas Diponegoro Semarang \\ ${ }^{2}$ Department of Social Anthropology, Faculty of Humanities, Universitas Diponegoro Semarang
}

\begin{abstract}
This study focuses on the pattern of community resistance affected by the Brown Canyon sand mining in Semarang. The community response that should occur when there is sand mining with indications of environmental damage is open resistance. This study tries to provide another picture from previous research, about how the community does not take open resistance to sand mining activities. The research method used is ethnography with research instruments in the form of participatory observation, interviews and literature studies. Determination of informants is based on the radius of the distance to the community most affected by mining activities. The results showed that the resistance pattern of the affected community was based on four factors. First, the community is indifferent to access to information about environmental issues such as impacts and mining permits. Second, the community considers the owner of the mine to be from their environment which should not be rejected. Third, the community feels that the opening of jobs from mining activities is an advantage for them. Fourth, the community realizes that the political power of mining owners is very strong to be resisted. These four factors then form a closed resistance pattern or hidden transcript according to Scott.
\end{abstract}

\section{Introduction}

Indonesia is one of the countries in the world that has abundant natural resources. The natural wealth is then widely spread in areas that can be utilized in mining activities. In UU No. 4 (2009), which regulates Mineral and Coal Mining, the concept of mining is part or all of the stages of activities in the context of research, management, and exploitation of minerals or coal involving general investigations, exploration, feasibility studies, construction, mining, processing and refining, transportation and sales, and post-mining activities.

One of the most significant contributors to rock mining activities in Indonesia is sand mining. According to BPS data, at least 59,725 businesses carry out sand mining activities (BPS, 2017). The mining activities are widely spread in West Java, East Java, and Central Java. As the capital of Central Java, the city of Semarang has natural potential that can be used as a mining location. In Rowosari Village, Tembalang District, a hill stretch is built from a rock material called Brown Canyon. This place became famous because of the beauty of its rocky curves that resemble the rocks of the Grand Canyon in America. Brown Canyon had become a frequently visited tourist site until this area was only used as a strategic location for sand mining activities.

The mining process is always connoted by destroying the ecology. Biodiversity is disrupted both in its distribution and the abundance of species around the mining area (Nur, 2014). Air pollution caused by dust from mining activities and noise pollution from trucks carrying sand creates discomfort for residents around the mining site. Not to mention the access roads that are often damaged by trucks and heavy equipment. These impacts can be classified as a form of environmental damage. This can also trigger social impacts due to the disruption of children's playgrounds around mining sites due to access to sand transport vehicles and mining sites that are dangerous to the public. The same thing was conveyed that sand mining also causes a decrease in agricultural land and plantations, thereby reducing farmers' sources of income (Hallatu et al., 2021).

Maximus Regius (2011), in his research on mining and people's resistance, wrote how local resistance continues to occur at the Manggarai mining site, East Nusa Tenggara. Among them, the causes are ecological degradation and socio-

\footnotetext{
* Corresponding author: anggasatriaw18@gmail.com
} 
cultural degradation due to mining activities. These two things are the leading causes of local resistance. In this study, it is described that when there is ecological degradation and socio-cultural degradation, the emergence of resistance from the community.

Another study from Suliadi (2015) examined farmers' resistance to sand mining in Karangwuni Kulonprogo stated that rejection happened. He called the emergence of peasant resistance as an implication after the fall of the New Order. The opening of democratic faucets greatly influenced this, closed for a long time. Suliadi called it a peasant community in the villages that were initially only used as an object of politics and development. It has now become a society that is active in politically organizing itself, even to the point of firm rejection in demonstrations. This refusal was based on mining activities that were connoted as the leading cause of agrarian conflicts.

The two studies have a similar research context. The similarity lies in the response and consequences resulting from sand mining activities. Both illustrate the existence of open rejections that occur in various forms as a community defense measure to prevent vertical conflicts and environmental pollution.

The communities around the affected Brown Canyon should be able to take more open actions to respond to this phenomenon, according to studies that show the community's attitude affected by environmental pollution due to sand mining. However, they tend to passively respond to environmental pollution problems caused by sand mining in Brown Canyon.

Departing from the phenomena mentioned above, the author would like to review the community's actual pattern of resistance and what makes the community not take open resistance, according to James Scott. This research also shows a difference with previous studies, which show a lot of open resistance responses due to resistance to mining activities that indicate environmental pollution, as mentioned above.

\section{Method}

In this research, the writer uses the ethnographic method. Ethnography is the work of describing culture. The primary purpose of ethnography is to understand other ways of life from the original point of view or what is commonly referred to as the emic point of view. As Malinowski put it (in Spradley, 1980), the aim of ethnography is "to understand the point of view of the natives, their relation to life, to realize their vision of their world."

The ethnographic principles that need to be considered are holistic or comprehensive. That is, all aspects of culture must be successfully photographed to become an ethnographic record. This is what distinguishes ethnographic research from other research. To achieve this, ethnography requires special data collection techniques to strengthen ethnographic records. At least three data collection techniques can be used in the ethnographic method, including observation, ethnographic interviews, and literature or documentation studies.

Departing from this title, the selection of informants is focused on affected communities in various circles and professions, namely those within a radius of $1-2 \mathrm{~km}$ from the mining site. This radius limitation is carried out to provide clear boundaries regarding the definition of affected communities. The affected community in question is the community that receives direct physical and non-physical impacts from mining activities or the communities that are traversed by the transportation of mining activities. Therefore, to facilitate field mapping, the research location is focused on Rowosari village. Furthermore, informants will target local government officials, communities, and parties related to mining companies.

The research instrument used in the form of Snowball Sampling is a sample collection technique that begins with a small number of target informants and then enlarges along with the research process. Researchers observed the community and sand mining activities at the research site. Objects that will be observed range from community activities in daily life to mining activities. Researchers also conducted in-depth interviews based on interview guidelines prepared previously so that the interview process went according to the formulation of the problem.

\section{Brown Canyon and Mining Impact 3.1 Geographical Conditions}

Rowosari Village is an area that has quite a broad natural potential. In addition to being suitable as agricultural land, this area also has mountainous land that can be used as a sand excavation site. Soil texture in solid rock can be used as raw material for making sand, which is currently referred to as Brown Canyon. The mention of this name is also obtained from the contours of the rocks that resemble the rocks in the American Grand Canyon.

In the 1990s, the Brown Canyon area was mountainous. So that at that time, many people used their land to be planted with plantation commodities. However, with Brown Canyon as a location for quarrying sand and solid rock, now the mountains have turned into hollow holes due to years of mining activities. Before the $2000 \mathrm{~s}$, the surface conditions of the settlements around Brown Canyon were under the mountains. Currently, the settlements are higher than in the Brown Canyon area. This shows that mining activities have changed the geographical conditions of Brown Canyon.

Another change that can also be seen from Brown Canyon is the condition of the trees or plants. With its geographical condition as a mountainous area, Brown Canyon was once known as a green area. In addition to wild trees that grow, it also looks green due to plantation activities carried out by residents. However, it is very different from the current conditions. Brown Canyon today is a vast land that is arid and dusty. There is almost no green area in the area, especially around the mining site. The image below shows the development of the geographical condition of Brown Canyon from time to time taken from satellite imagery. 


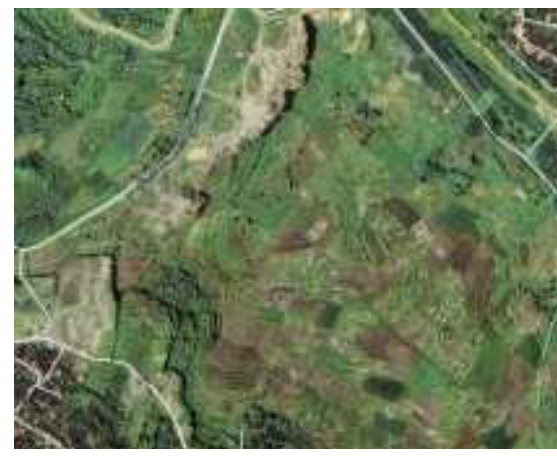

Figure 1. Brown Canyon (2002)

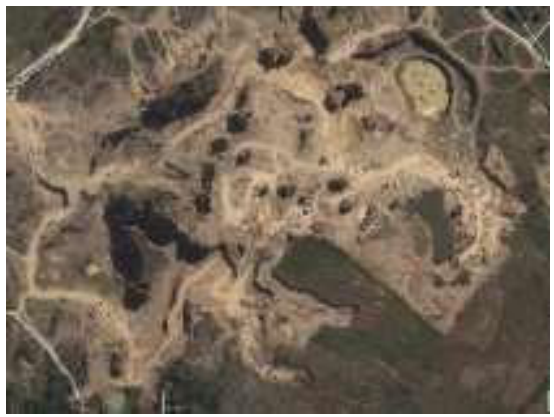

Figure 3. Brown Canyon, (2012)

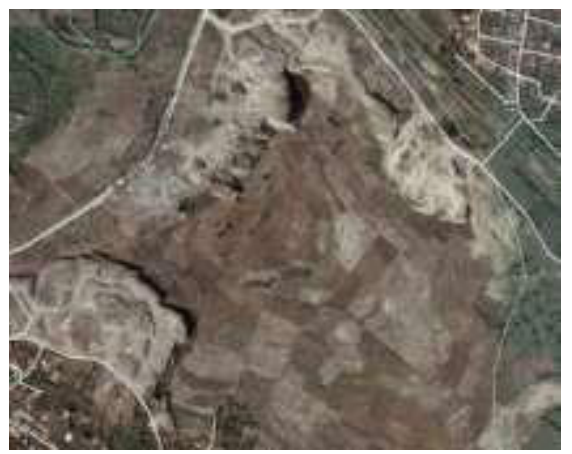

Figure 2. Brown Canyon, (2007)

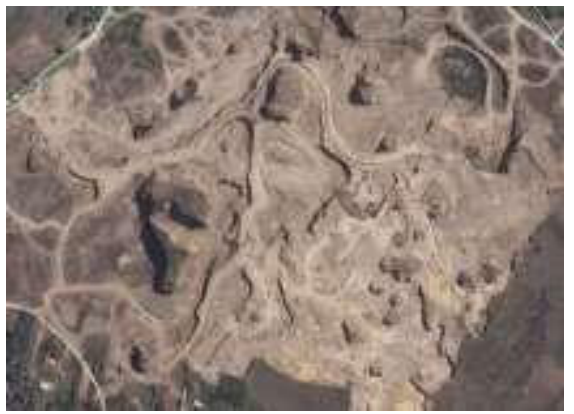

Figure 4. Brown Canyon (2014)

Source: https://nursidqon.blogspot.com

The satellite image above illustrates how the geographical conditions changed from a green mountainous area to a basin hole dredged as a mining location. The picture also shows the height difference that changes from time to time. In other words, Brown Canyon's surface level is decreasing over time.

\subsection{Physical Impact of Mining}

Environmental problems can be divided into two forms, namely, environmental pollution and resource depletion. According to UU No 32 (2009) concerning the Environment, environmental pollution is the entry or inclusion of living things, substances, energy, and/or other components into the environment by human activities to exceed the established environmental quality standards. The types of environmental pollution that are commonly known are; First, air pollution, which is usually caused by factory fumes or forest fires; Second, water pollution, which is usually caused by factory waste dumped into rivers; Third, noise pollution, which is usually caused by vehicle noise; Fourth, soil pollution, which is usually caused by spills of hazardous chemicals.

Environmental problems in the form of pollution mentioned above can also occur in mining activities. This is in line with the opinion of Yudhistira et al. (2011), which states that sand mining using heavy equipment to dredge material on the plains or cliff walls causes ecological and social problems for the surrounding environment. According to Yudhistira et al., one of the indicators of environmental pollution is erosion caused by mining. The problem of erosion is what ultimately causes environmental pollution in other forms.

This happened at the Brown Canyon sand mining site, Rowosari Village, Tembalang District, Semarang. The dredging, which has been accompanied by natural resources since the 1980s, has led to the exploration of natural resources. The dredging of land to create deep basins is a long-term impact on the surrounding community. Especially on the environmental impact that is still happening today.

\subsubsection{Lack of Water Availaibility}

Sand mining activities will undoubtedly change the soil layer. In addition to changes in soil layers, mining activities also leave steep high cliffs. The condition of the soil is steep, and no vegetation covers and supports it; it can be ascertained that the erosion rate is very high. When the erosion rate is high, the risk of erosion will also be high. This erosion hazard mainly occurs in areas with dry land and slopes of about $15 \%$ or more. This condition is a consequence of wrong water and soil management and does not follow the soil and water conservation rules as it should (Yudhisthira, 2011). The impact of erosion is usually identical to that of a landslide, but the erosion process also impacts the infiltration process. The loss of components of the soil layer and the absence of vegetation covering the soil causes the soil to be less able to absorb water so that groundwater availability will decrease. In addition to reducing groundwater availability, it also 
causes the water to be cloudier than before; this is due to the reduced layer of soil that filters incoming water.

This was conveyed by BR (39), who is a community affected by mining activities.

\begin{abstract}
"Previously, very little water was supplied to residents. Sometimes I have to keep (water) until midnight just to wait for the water to flow. The water that comes out is little by little and a bit cloudy."
\end{abstract}

The cloudy water is also allegedly due to the effects of pollution from garbage around the mining area. This mining area is also used as a garbage dump by the mine manager and the community around Brown Canyon. By making it a landfill, the existing water will be polluted and absorbed into the ground. So that the water conditions in the Brown Canyon mining area have poor quality.

\title{
3.2.2 Road Damage
}

Road conditions in the Brown Canyon mining area and its surroundings are often damaged. This road damage is due to the weight of the vehicles that pass through the road being too heavy or not following the strength of the road in the Brown Canyon area. The Brown Canyon Mining produces hundreds of trucks of sand every day, so many trucks are passing through the streets in the Brown Canyon area. Due to the high traffic and heavy trucks that carry sand every day, it certainly causes road damage.

When reviewed regarding the specifications of the sand transport truck, this sand transporter weighs 2.3 tons when empty and weighs 5 tons when the tub is filled. In a day, if 200 trucks cross the Brown Canyon area, then there will be 1000 tons of weight pounding the roads in the area. Meanwhile, the road built had not been reinforced by concrete, so the load-bearing strength was inferior.

\subsubsection{Air Pollution}

In addition to the problems caused by transport trucks, the location of the Brown Canyon sand mining site also has excavated holes that are used as a place to accommodate garbage. Of course, this garbage collection produces an unpleasant odor. Some of these garbage shelters are located very close to residential areas so that residents can smell the unpleasant odor from the accumulated garbage. In addition to producing odors, this waste is also managed by burning.

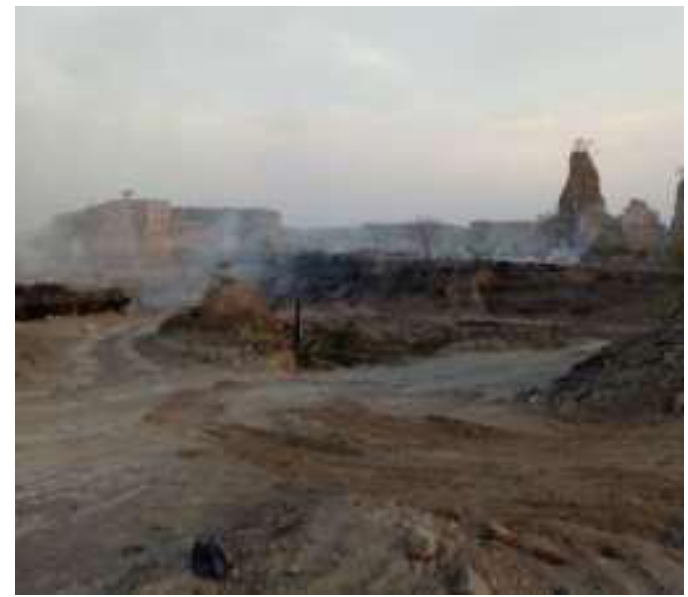

Figure 5. Brown Canyon Dumpster

Burning waste can be seen as a very effective way of reducing waste, but the smoke resulting from burning waste can pollute the air. Open burning of waste will cause greenhouse gas (GHG) emissions. Greenhouse gases are gases in the atmosphere. This gas has the property of absorbing and emitting infrared radiation from sunlight. Greenhouse gases (GHG) can arise naturally or due to human activities. In the long term, greenhouse gases can cause climate change (Wahyudi in Jatmiko, 2019). This is because the heat contained in infrared is trapped in greenhouse gases (GHG) which causes an increase in temperature on the earth's surface.

\subsubsection{Potential Disaster}

Sand mining activities in Brown Canyon can cause disaster. The steep, high, and unterraced cliffs formed by mining activities are indeed very prone to landslides. Landslides have occurred at the Brown Canyon mining site, precisely in 2019. In the news article "Brown Canyon Landslide Tourism Location, 7 Buried Project Trucks," published in jatengtoday.com, it was explained that there had been a landslide at the Brown Canyon sand mining site on 20 February 2019. The article stated that the landslide that occurred was very severe, which caused one person to be injured and seven trucks buried under the landslide. It was stated that the landslide that occurred at the Brown Canyon sand mining site was due to poor soil conditions.

In addition to the steep and high cliffs, mining activities also leave deep holes and cause groundwater to come out by 
itself, creating puddles like lakes. This lake is also considered dangerous because the mining site is very close to settlements and many visitors at the mining site, allowing accidents to occur. As has happened, a child fell in a lake excavated in Brown Canyon. Quoted from the news article "The Boy Drowning in Brown Canyon Semarang Found Dead" published in DetikNews, at least three children were playing in a puddle of ex-excavated water. It turned out that the depth was uneven and trough. However, there was one child who drowned because he entered a deeper area. The drowned child was found dead after a lengthy search. Of course, the location of Brown Canyon, which has holes and cliffs, is very prone to disasters and accidents.

\section{Discussion}

\subsection{Assistance and Employment}

A family company manages mining activities at Brown Canyon. The company was formed and managed by a family with a long track record. Historically, since 1985 mining activities began, mining management has only been traditional and individual. People are free to dredge their land and then sell it as a building material. The tools used are still traditional with hoes, shovels, and stone-breaking hammers.

The owner of a sand mining company in Brown Canyon, a native of Rowosari, has a relatively harmonious relationship with the surrounding community. There tends to be no open rejection by the community of these mining activities. About the relationship between the company owner and the community, at least two things were decisive in the harmonious relationship between the company owner and the community, namely employment opportunities and assistance from the manager. The informants always mention these two things during the research process. Employment is related to people whose welfare is affected by getting a job. Meanwhile, the assistance from the management relates to the reciprocity received by the community from the company that has been doing mining business around their residential area.

Before this mining activity experienced rapid development, most of the people of Brown Canyon worked in agriculture. By taking advantage of the geographical conditions in the form of mountains, they plant secondary crops. Among those chosen by the people at that time were corn, cassava, and cassava. In addition to the types of secondary crops, the community also grows rice in relatively small quantities because the soil texture is not very suitable for this plant. These livelihood conditions subsequently underwent significant changes after the development of sand mining activities in Brown Canyon. Along with the land-use change that occurred, the community also experienced a change of profession. The need for much staffing in the mining sector makes people think of working in Brown Canyon mining. This is reinforced because many of their agricultural fields are sold as excavation points for the $\mathrm{C}$ excavated material. The majority of them fill the vacancies needed for work in the stone crusher section.

In addition to the availability of job opportunities as described above, another thing that is also a decisive factor in the harmonious relationship between the mine manager and the surrounding community is assistance to the community. People often get help, either in the form of money or in kind. The existence of mine managers who live amid the community is the cause of routine assistance distributed to the community. In the research conducted, the authors collect information about the assistance that the family management has given.

The direct assistance that the manager often gives to the community is financial assistance and necessities. This assistance is routinely distributed every week to widows and the elderly. Indeed, not all communities have the right to receive this assistance. Communities that fall into the category are selected and sorted by each head of the neighborhood. After sorting, the neighborhood head submitted the names to the manager to be registered as beneficiaries. Mine managers also routinely give Umrah gifts to their workers. Every year the mining family always sends their chosen people to the holy land. At every significant religious moment, such as Eid al-Fitr and Eid al-Adha, the management family also assists in the form of necessities or cash.

In health facilities, the mine manager also has a private ambulance that can be borrowed for free by the Rowosari community. This ambulance belongs to the mine manager, and anyone who needs it can use it according to their needs. There has never been a community that is not allowed to use the ambulance, as long as the borrower is the Rowosari community.

\subsection{Public Perception of Mining}

One of the crucial things to discuss in finding patterns of resistance is the matter of perception. Perception has meaning as a cognitive process experienced and obtained by each individual about understanding information about the environment through sight, hearing, appreciation, feeling, and smell (Thoha in Rahmadian, 2014). Concerning mining, this perception is obtained from what factors are experienced by the community as affected subjects.

The author classifies the perception of the affected community into four aspects. The first is the ecological aspect which discusses the community's perception of the perceived environmental impact. Second is the social aspect that talks about relationships within the community itself or with mine managers who are also involved. The third is the economic aspect that explains the condition of community welfare due to this sand mining activity. Fourth is the political aspect that discusses people's perceptions of the political situation or power in the field.

The connotation of environmental impacts resulting from mining activities is not a significant consideration for the surrounding community in the ecological aspect. Dusty roads, potential disasters, and environmental pollution are seen as something that can be accepted. They feel it can be adjusted easily, without having to think long term. Changing professions is not a problem for them, as long as they can get a good income.

One of the informants, TK (55), conveyed this when asked about mining permits. 


\title{
"If it's the boss's business, we don't know and don't want to find out. Not in our capacity to find
} out. We don't want to be said to know a lot when we take care of it".

In the social aspect, the community admitted that they did not protest because they felt that the mine managers were their neighbors. In this case, the manager comes from the Rowosari community. One of the informants firmly said that he would not protest because the management is part of their environment. According to him, this might be different if the people doing the mining are from outside Rowosari. The community understands that indigenous people from Rowosari use their land, regardless of the process and activities. In addition, the community feels that the mine management has provided much assistance. All assistance provided is considered a substitute or payment for the impact of mining activities. Another perception is that this assistance is a caring attitude towards their neighbors who are still in need.

One of the informants, AS (40), conveyed this when asked about mine manager.

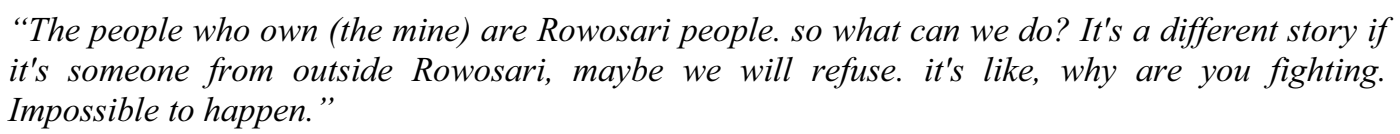

In the economic aspect, the community considers that they have felt development in welfare-the availability of employment opportunities they perceive as a positive and crucial impact for them. In fact, according to them, the existence of mining is fundamental because people can get jobs. Income is indeed the main factor that people accept mining activities. The economic condition of the people who used to be poor became a reason to at least accept whatever impacts arise from mining. In addition, the community can also open stalls for mining workers. This is also considered a welfare development due to mining activities.

One of the informants, BK (53), conveyed this when asked about the economic impact of mining.

"Many people work in mining. For example, they become truck drivers, can get daily wages and
food allowance. There are also stone crushers, they work in groups and their wages are divided
equally. There are also those who open coffee and cigarette shops. This is said to increase
revenue. Especially if you get help from the manager"

In the political aspect, the community does not reject or openly fight because they feel that the mine managers have power or power that is not commensurate with them. Mine managers are indeed a respected family in Rowosari who have always had a strong influence. Until now, the management must influence various affairs and problems in the community as a respected figure.

One of the informants, RF (51), conveyed this when asked about the manager's position.

\begin{abstract}
"The people here are ashamed of his family. They have always been respected. They are good but firm people. That's why no one dares. Everyone must respect, including if there are problems in the community. They must have finished."
\end{abstract}

\subsection{Brown Canyon Community Resistance Pattern}

James Scott revealed that resistance or resistance is manifested in two forms, namely: First open resistance or public transcript. The second is a closed resistance or hidden transcript. Open resistance or public transcript is a form of resistance displayed in front of the general public or related parties. At the same time, closed resistance or hidden transcript is a form of resistance that is not displayed in public. This means that this form of resistance is carried out secretly, hiding or acting behind the scenes.

In his 1990 book "Domination and the Arts of Resistance: Hidden Transcripts," Scott argues that all subordinate groups choose to use strategies that only groups tend to ignore. This is what he calls 'infrapolitics.' From this pattern, Scott tries to describe the open public interaction between the dominator and the oppressed as a "public transcript" and the criticism of power that takes place offstage as a "hidden transcript."

Scott then defines this as a hidden transcript or closed resistance carried out in silence. The forms of resistance are different in each conflict, especially in the articulation of resistance shown by the community. However, according to Scott, what is certain is that this hidden transcript always occurs between the subordinate class and the superordinate class. In this context, the attitude of resistance in the form of protests that are not conveyed becomes a form of community resistance to mining activities. The fear of not getting help or the consequences of becoming a 'common enemy' encourages them always to respect all management decisions.

The public perception captured from this research is the basis for the construction of James Scott's theory in defining the form of resistance. Scott classifies the passive attitude of the community towards mining activities as a closed refusal or hidden transcript. This form of resistance is manifested by people who claim they do not dare to oppose the management's policies. This phenomenon does not mean that what happened in the field was zero resistance but that the existing resistance had to be canceled. This lack of courage then formed a pattern of community resistance as the subject was affected by this mining activity. Of course, in concluding the pattern of community resistance, it is based on their perception of all the aspects described previously. This pattern of resistance simultaneously describes the "other response" made by the community towards mining activities after other studies have shown open resistance or public 
transcripts to a similar phenomenon.

This kind of complexity becomes a novelty or novelty of the premise of Scott's thinking related to community resistance. In James Scott's books and writings, society always takes excellent and open resistance in responding to the critical conditions they experience. However, in this Brown Canyon phenomenon, what happens is the opposite. People do not do open resistance with reasons and thoughts that have been imprinted as a form of adaptation and resistance patterns. This can also be strengthened by the cultural factors of the 'legowo' Javanese society. The habit of forgiving and accepting can be correlated to the social actions of the Brown Canyon community, who are "cool and calm" in accepting sand mining activities. Emphatic Moral and Forgiving Moral can be taken as a value from society. Emphatic Moral relates to the perception of those who feel that mine managers are part of their environment so that whatever is done needs to be supported. Meanwhile, Forgiving Moral relates to the actions of those who accept all forms of mining impacts on the condition that they receive reciprocity, or in this case, work and assistance from the manager.

\section{Conclusion}

At least four aspects related to people's perceptions make them discourage their intention to carry out open resistance. First, they do not care and want to seek information about environmental issues such as impacts and mining permits. Second, they do not take open resistance because the owner and manager of the mine are part of their environment. The community also feels that the mine management has provided much assistance so far. They consider this assistance as an attitude of concern for the management towards the communities affected by sand mining. Third, they have a perception that improving welfare with employment is the most important thing because of the existence of this mining. Fourth, they did not take open resistance because they realized the position and strength of the mine manager was quite strong. As is well known, the mine manager comes from a well-known family and has more capability to control the area. These perceptions embedded in their cognition system form the resistance pattern of the people affected by Brown Canyon. Starting from not having the courage to speak up and ignoring access to information about mining activities, the community accepts all the decisions and policies that have been determined by the mine manager, which they call the "big boss." This pattern of resistance, which is often manifested in various affairs related to the community, is influenced by mine managers. Although the impacts of mining are pretty dangerous and the assistance to the community is not commensurate with what is received by the managers, they feel that this has become a situation that must be accepted and adjusted. This kind of phenomenon is what Scott calls a hidden transcript or resistance that does not appear in public. This resistance can be manifested in the form of complaints that are not conveyed or mere gossip. People feel they are being dominated but cannot fight this domination with open behavior.

\section{References}

1. Bestar, Niknik. SKRIPSI Studi dan Kuantifikasi Emisi Pencemar Udara Akibat Pembakaran Sampah Rumah Tangga secara Terbuka di Kota Depok. Depok: Universitas Indonesia. 2012

2. Darsihardjo, dkk. Pengaruh Penambangan Pasir terhadap Kualitas Lingkungan di Kecamatan Sukratu kabupaten Tasikmalaya. Antologi Pendidikan Geografi, Volume 3, Nomor 1, April. 2013

3. Friedman, Jonathan. Globalization, Class, and Culture in Global Systems. Journal of World System Research 6(3):636-656. 2000

4. Emmanuel, Godwin. Management Thoughts: The Review of Social Action Theory. SSRN Electronic Journal. 2016.

5. Hallatu, Reinhard et al. Illegal Sand Mining and Sar Local Wisdom: A Case Study in Merauke. International Journal of Social Sciences and Humanities. Volume 5, No.1, 2021

6. Ilyasa, Feryl. Pengaruh Eksploitasi Sumber Daya Alam Perairan Terhadap Kemiskinan Pada Masyarakat Nelayan. Jurnal Pendidikan Lingkungan dan Pembangunan Berkelanjutan, Volume XXI Nomor 01, Maret . 2020

7. Nainggolan, Patmasari. Resistensi Penambangan ilegal : Studi Kasis Eksploitasi Tambang Galian B (Emas) di Desa Sayurmatua Kecamatan Naga juang Kabupaten Mandailing Natal. Jurnal Buana, Volume 2, No. 3. 2018

8. Nuryati.. Statistik Pertambangan Bahan Galian Indonesia. Jakarta: Badan Pusat Statistik. 2017

9. Nur, Muhammad. SKIPSI Resistensi Penambang Ilegal: Studi Kasus Eksploitasi Tambang Galian C (Pasir) di Desa Borimasunggu Kabupaten Maros. Makassar: Universitas Hasanuddin. 2014

10. Pawito. Penelitian Komunikasi Kualitatif. Yogyakarta: LKiS Pelangi Aksara. 2007

11. Rahmadian, Faris. Ideologi Aktor dan Persepsi Masyarakat terhadap Dampak Pertambangan Pasir di Pedesaan Gunung Galunggung. Bogor: Jurnal Sosiologi Pedesaan, Vol.02, No.02. 2014

12. Regius, Maximus. Tambang dan Perlawanan Rakyat: Studi Kasus Tambang di Manggarai, NTT. Jakarta: Jurnal Sosiologi, Vol.16, No.1. 2011 
13. Sari, laela Nur Indah. Dampak Tambang Pasir terhadap Kerusakan Jalan di Desa Babadan Kecamatan Wlingi kabupaten Blitar. Swara Bhumi, Volume V Nomor 8. 2020

14. Scott, James. Domination and The Arts of Resistance: Hidden Transcripts. New Haven and London: Yale University Press. 1990

15. Scott, James. Senjatanya Orang-Orang yang Kalah. Jakarta: Yayasan Obor Indonesia. 2000

16. Spradley, James. Participant Observation. Orlando: Harcourt Brace Jovanich College Publishers 1980

17. Suliadi. Resistensi Petani terhadap Pertambangan Pasir Besi di Karangwuni Kulon Progo. Yogyakarta: Jurnal Sosiologi Reflektif, Vol.9, No.2. 2015.

18. Wahyudi, Jatmiko. Emisi Gas Rumah Kaca (GRK) dari Pembakaran Terbuka Sampah Rumah Tangga Menggunakan Model IPCC. Jurnal Litbang, Volume XV No. 1. 2019

19. Yudhistira, dkk. Kajian Dampak Kerusakan Lingkungan Akibat Kegiatan Penambangan Pasir di Desa Keningar daerah Kawasan Gunung Merapi. JURNAL ILMU LINGKUNGAN Volume 9, Issue 2: 76-84. 2011 